\title{
Phosphatase Synthesis in a Citrobacter sp. Growing in Continuous Culture
}

\author{
By SUSAN G. HAMBLING, $\dagger$ LYNNE E. MACASKIE $\ddagger$ AND \\ ALASTAIR C. R. DEAN* \\ Physical Chemistry Laboratory, University of Oxford, South Parks Road, Oxford OXI 3QZ, UK
}

(Received 30 March 1987)

\begin{abstract}
When a Citrobacter sp. was grown aerobically at $D=0.5 \mu_{\max }$ in glycerol-limited chemostat culture, maximum phosphatase specific activity was obtained at $30^{\circ} \mathrm{C}$ and $\mathrm{pH} 7 \cdot 0$. This was a four-fold increase on the maximum activity obtained in batch culture and detailed tests implicated an atypical acid-type phosphatase. The activity was very resistant to cadmium, confirming an earlier postulate that a cadmium-resistant phosphatase was indispensable for the high uptakes of cadmium (as $\mathrm{CdHPO}_{4}$ ) obtained with this strain. Cobalt and nickel also had little effect on activity, but zinc was inhibitory at $\mathrm{pH} 7.0$ and copper at $\mathrm{pH} 5.0$ and 7.0 . The enzyme was not activated by $\mathrm{Mg}^{2+}$ and the cells could be stored in saline for at least $17 \mathrm{~d}$ without any loss of phosphatase activity.
\end{abstract}

\section{INTRODUCTION}

A strain of Citrobacter isolated from soil heavily polluted with lead (Macaskie \& Dean, 1982) grew in cadmium-supplemented minimal medium and accumulated the metal during growth (Macaskie \& Dean, 1984a). Washed cells pre-grown in cadmium-free medium showed enhanced metal accumulation upon subsequent exposure in the 'resting' state. This ability, retained when the cells were immobilized, has led to the development of a process for the removal of cadmium (Macaskie \& Dean, 1984b; Macaskie et al., 1987a) and other metals (Macaskie \& Dean, 1984c, 1985a, b, 1987) from aqueous solutions, with considerable potential for the removal of heavy metals from liquid industrial wastes (Macaskie et al., 1987a; Macaskie \& Dean, 1987).

Cadmium uptake is critically dependent on the presence of an organic phosphate (Macaskie \& Dean, 1984a, $b$; Michel et al., 1986) in the metal solution, and since uptake increased linearly with time an enzymic mechanism was implicated. It seemed likely that a surface-located phosphatase, produced during pre-growth, continued to cleave organic phosphate in the resting and whole-cell immobilized states to precipitate the metal with liberated inorganic phosphate at the cell surface. This has been demonstrated with another Citrobacter sp. able to accumulate lead as $\mathrm{PbHPO}_{4}$ (Aickin et al., 1979), but this latter strain accumulated very little cadmium (Macaskie \& Dean, 1982, 1984b). Since cadmium is inhibitory to many enzymes (Vallee \& Ulmer, 1972) it is likely that the phosphatase of the lead-accumulating strain was inhibited by $\mathrm{Cd}^{2+}$; it was suggested that the ability of the metal-non-specific Citrobacter sp. to accumulate cadmium was due to a reduced susceptibility of its phosphatase to cadmium toxicity (Macaskie $\&$ Dean, 1984a). This would also account for the ability of the organism to grow in $\mathrm{Cd}^{2+}$ supplemented media (Macaskie \& Dean, 1982, 1984a) by removal of the metal from the cellular micro-environment by precipitation as $\mathrm{CdHPO}_{4}$ (Macaskie et al., 1987b).

† Present address: Department of Biochemistry, University of Edinburgh Medical School, Hugh Robson Building, George Square, Edinburgh EH8 9XD, UK.

† Present address: Microbiology Unit, Department of Biochemistry, University of Oxford, South Parks Road, Oxford OX1 3QU, UK

$0001-4110 @ 1987$ SGM 
Previous studies have been performed using cells pre-grown in batch culture, but the large biomass required for an economic industrial process necessitates the use of continuous culture (Tempest, 1984). It has been established that immobilized cells taken from continuous cultures are as effective in cadmium removal as batch-pregrown cells (Michel et al., 1986), and in this investigation we compare the phosphatase titres obtained with both types of culture. The effect of cadmium and other heavy metals on the enzyme activity is also reported and related to the known performance of whole cells in metal accumulation. The involvement of a highly atypical phosphatase is suggested and this conclusion is further substantiated by an investigation into the effects of various compounds reported to activate or inhibit classical phosphatases.

\section{METHODS}

Grow th of the organism. The Citrobacter sp. was grown in carbon-limiting continuous culture in medium having the following composition $\left(\mathrm{g} \mathrm{l}^{-1}\right)$ : Tris, $12.0 ;\left(\mathrm{NH}_{4}\right)_{2} \mathrm{SO}_{4}, 0.96$; glycerol 2-phosphate (disodium salt hydrate, $5 \cdot 5$ $\left.\mathrm{H}_{2} \mathrm{O}\right) 0.67 ; \mathrm{KCl}, 0.62 ; \mathrm{MgSO}_{4} .7 \mathrm{H}_{2} \mathrm{O}, 0.063 ; \mathrm{FeSO}_{4} .7 \mathrm{H}_{2} \mathrm{O}, 0.00032$, glycerol, 0.6 ; with the pH adjusted, as necessary, with $2 \mathrm{M}-\mathrm{HCl}$ (usually to $\mathrm{pH} 7$ or as otherwise stated in the text). Polypropylene glycol antifoam was incorporated at $1 \mathrm{ml}$ per 101 medium. The cultures were maintained at $30^{\circ} \mathrm{C}$, except where otherwise specified, in a New Brunswick 'Bioflo' apparatus (agitation 400 r.p.m.; air flow $0.51 \mathrm{~min}^{-1}$ ) at dilution rates $(D)$ from 0.048 to $0.40 \mathrm{~h}^{-1}$ initially and at $D=0.5 \mu_{\max }\left(0.25 \mathrm{~h}^{-1}\right)$ in later experiments. The $\mu_{\max }$ (maximum specific growth rate) was (mean \pm SEM, three experiments) $0.41 \pm 0.00,0.51 \pm 0.01$ and $0.53 \pm 0.02$ at 25,30 and $35^{\circ} \mathrm{C}$ respectively. These growth rates were determined in batch culture using the medium described above except that the glycerol concentration was increased to $1.5 \mathrm{~g} \mathrm{1}^{-1}$. Steady states were reached in the chemostats after 24 generations of growth after which the chemostat outflow was collected at $0{ }^{\circ} \mathrm{C}$.

Harvesting and storage of the cells. The cells in the culture outflow were separated by centrifugation (MSE Mistral, $\left.5000 \mathrm{~g}, 15 \mathrm{~min}, 0^{\circ} \mathrm{C}\right)$, washed once in isotonic saline $\left(8.5 \mathrm{~g} \mathrm{NaCl} 1^{-1}\right)$ and stored at $4^{\circ} \mathrm{C}$ prior to use. The

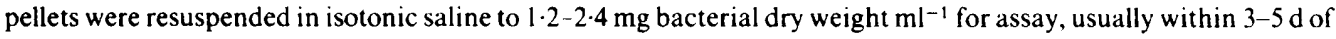
harvest.

Assay of phosphatase activity. Phosphatase activity was estimated by the liberation of $p$-nitrophenol from p-nitrophenyl orthophosphate (disodium salt, BDH) as described by Bolton \& Dean (1972). Samples (1 ml) of the concentrated bacterial suspension (see above) were diluted to $10 \mathrm{ml}$ in several buffers: $0.2 \mathrm{M}$-sodium acetate $/ \mathrm{NaOH}, \mathrm{pH} 5 \cdot 0 ; 0.2 \mathrm{M}-\mathrm{MES} / \mathrm{NaOH}, \mathrm{pH} 5 \cdot 0 ; 0.2 \mathrm{M}-\mathrm{Tr}$ is $/ \mathrm{HCl}, \mathrm{pH} 7.0$ or $8.5 ; 0.2 \mathrm{M}-\mathrm{MOPS} / \mathrm{NaOH}, \mathrm{pH} 7 \cdot 0$; or $0.2 \mathrm{M}$-Tricine $/ \mathrm{NaOH}, \mathrm{pH} 8.5$. Magnesium chloride $\left(0.1 \mathrm{ml}\right.$ of $\left.0.15 \mathrm{mM}-\mathrm{MgCl}_{2} .6 \mathrm{H}_{2} \mathrm{O}\right)$ was added and the mixture was pre-equilibrated at $30^{\circ} \mathrm{C}$ for $15 \mathrm{~min}$ prior to the initiation of the reaction by the addition of $45.6 \mathrm{~mm}$ p-nitrophenyl disodium orthophosphate $(2 \mathrm{ml})$. Timed samples $(2 \mathrm{ml})$ were quenched in $4 \mathrm{ml} 0.2 \mathrm{M}-\mathrm{NaOH}$ and the liberated $p$-nitrophenol was estimated by measuring $A_{405}$. Phosphatase specific activity is defined as nmol $p$-nitrophenol liberated $\min ^{-1}$ (mg bacterial protein $)^{-1}$, with bacterial protein determined by the Lowry method.

To test the effect of a heavy metal, activator or inhibitor, the cells were pre-equilibrated for $1.5 \mathrm{~h}$ in the reaction mixture containing the agent under test prior to the addition of $p$-nitrophenyl phosphate. Metal solutions were freshly prepared prior to their use and controls were performed to ensure that no metal precipitation in cell-free media occurred. Where the phosphatase reaction yielded a metal phosphate precipitate the solid material settled out within $1-2 \mathrm{~h}$, and the clear supernatant could then be decanted prior to the estimation of $p$-nitrophenol.

\section{RESULTS AND DISCUSSION}

Buffer system for phosphatase assay:

The Citrobacter sp. was grown in carbon-limited continuous culture at dilution rates in the range $0.048-0.4 \mathrm{~h}^{-1}$ (corresponding to $0.09-0.78 \mu_{\max }$ at $30^{\circ} \mathrm{C}$ ), and its phosphatase activity was determined at $\mathrm{pH} 5 \cdot 0, \mathrm{pH} 7 \cdot 0$ and $\mathrm{pH} 8 \cdot 5$. Several buffers were used each appropriate over a limited $\mathrm{pH}$ range. At $\mathrm{pH} 5.0$ acetate buffer was used but since this was potentially metabolizable the non-metabolizable buffer MES (Good et al., 1966) was also used. The results obtained were very similar and both buffers were used subsequently. MOPS and Tris buffers gave identical results at $\mathrm{pH} 7 \cdot 0$. Tris was also used at $\mathrm{pH} 8.5$ since other commonly used alkaline-range buffers may inhibit (glycine and ethanolamine) or enhance (ethylaminoethanol and diethanolamine) phosphatase activity (Hausamen et al., 1967; McComb \& Bowers, 1972; Mossner et al., 1980). In some later experiments Tricine buffer was substituted for Tris. This did not affect the phosphatase activity. 
Phosphatase activity of the cells

Irrespective of the assay $\mathrm{pH}$ the phosphatase specific activity increased linearly with the dilution rate at which the cells were grown. The protein content per mg bacterial dry weight was invariant with the dilution rate. For convenience a dilution rate of $0.25-0.26 \mathrm{~h}^{-1}\left(0.5 \mu_{\text {max }}\right)$ was chosen for all subsequent experiments. The phosphatase specific activity of cells thus grown (assayed at pH 7.0) was $1349 \pm 71.75$ units (mean \pm SEM from five chemostats), giving a standard error between chemostats of within $6 \%$ of the mean. The phosphatase specific activity of glycerol-batch-grown cells similarly assayed was $326.96 \pm 3.43$ units (mean \pm SEM; three cultures); chemostat culture thus conferred a fourfold elevation of phosphatase activity as compared to batch culture for cells maintained continuously at $0.5 \mu_{\max }$; at $0.78 \mu_{\max }$ this ratio was increased to 5.4-fold.

For each of 10 chemostat cultures held at $D=0.25-0.26 \mathrm{~h}^{-1}$ the specific activity observed at an assay $\mathrm{pH}$ of 7.0 was afforded a value of 100 ; the specific activities at $\mathrm{pH} 5.0$ and 8.5 relative to this were $100 \cdot 17 \pm 1.37$ and $110.0 \pm 2.25$ respectively (mean \pm SEM; 10 cultures). Thus while the phosphatase activities assayed at acid and neutral $\mathrm{pH}$ were identical, the activity at $\mathrm{pH} 8.5$ was elevated by about $10 \%$, in accordance with similar findings using batch-grown cells. These batch culture experiments also established that no well-defined barrier to substrate access exists since disrupting the cells did not increase the activity. For example, the phosphatase specific activity of a saline suspension of cells was 335 units when assayed at $\mathrm{pH} 8.5$ after treatment for 6 min at $0{ }^{\circ} \mathrm{C}$ in a Mullard-MSE ultrasonic disintegrator compared to 330 units before treatment. Very similar results were also obtained at assay $\mathrm{pH}$ values of 5.0 and $7 \cdot 0$, and increasing the time of treatment led to a decrease in activity at all assay $\mathrm{pH}$ values.

Phosphatase activity was generally assayed at $30^{\circ} \mathrm{C}$, although enzyme activity was temperature-dependent. At all three $\mathrm{pH}$ values the activity increased linearly by $45-50 \%$ over a $10{ }^{\circ} \mathrm{C}$ rise in assay temperature from 25 to $35^{\circ} \mathrm{C}$. The enzyme was relatively heat stable, retaining $32 \%$ of its initial activity of 1349 units at $\mathrm{pH} 7.0$ after storage at $46.5^{\circ} \mathrm{C}$ for $3 \mathrm{~d}$.

The stability of the phosphatase in whole cells was further demonstrated. $\mathrm{Mg}^{2+}$ often confers enzyme stability (Van Belle, 1972) and is commonly included during phosphatase preparation. However, the cells could be stored as concentrated saline suspensions in the absence of added $\mathrm{Mg}^{2+}$ for up to $17 \mathrm{~d}$ (the longest time tested) without loss of activity. Similarly, although phosphatases are commonly activated by $\mathrm{Mg}^{2+}$ (Ahlers, 1974; Linden et al., 1977; Sugiura et al., 1981) the presence of added $\mathrm{Mg}^{2+}$ in the reaction mixture was unnecessary for full activity.

\section{Effect of growth conditions on phosphatase activity}

The $\mu_{\max }$ values for organisms grown at 30 and $35^{\circ} \mathrm{C}$ (see Methods) are not significantly different $(P=0.95)$ and hence a dilution rate of $0.26 \mathrm{~h}^{-1}$ (i.e. equivalent to $\left.0.5 \mu_{\max }\right)$ was used at both of these temperatures. However, the growth rate was significantly lower at $25^{\circ} \mathrm{C}\left(\mu_{\max }=\right.$ $\left.0.41 \mathrm{~h}^{-1}\right)$ and for the experiments at this temperature the dilution rate was accordingly adjusted to $0.21 \mathrm{~h}^{-1}$. Irrespective of the assay $\mathrm{pH}$, the activity of cells grown at $25^{\circ} \mathrm{C}$ was reduced by about $20 \%$ as compared to cells grown at $30{ }^{\circ} \mathrm{C}$.

Although the growth rate was identical at 30 and $35^{\circ} \mathrm{C}$, phosphatase activity was approximately sevenfold lower in cells grown at the higher temperature. Furthermore it varied considerably between chemostat cultures: under identical assay conditions the phosphatase specific activity of three cultures grown at $35^{\circ} \mathrm{C}$ was $238 \pm 118$ units (mean \pm SEM; range 29439 units), this variation occurring under all assay $\mathrm{pH}$ conditions. The culture with an activity of only 29 units did not wash out of the chemostat, and since phosphatase activity was therefore not growth-limiting it was calculated by comparison with the enzyme activity of cultures at $30{ }^{\circ} \mathrm{C}$ that phosphatase must have been present to at least a 45 -fold excess over growth requirements at the lower temperature. By deduction an excess of inorganic phosphate must have been present in the cultures grown at 25 and $30^{\circ} \mathrm{C}$ and the role of phosphate was investigated further. Replacing the glycerol 2-phosphate in the carbon-limited medium with inorganic phosphate $\left(\mathrm{Na}_{2} \mathrm{HPO}_{4} .12 \mathrm{H}_{2} \mathrm{O}, 1.52 \mathrm{~g} \mathrm{l}^{-1}\right)$ was without effect, at all three assay $\mathrm{pH}$ values. However, changing the nutrient status of the medium from carbon-limitation to phosphate-limitation (glycerol 2-phosphate disodium salt hydrate, $0.066 \mathrm{~g} \mathrm{l}^{-1}$; glycerol, $3 \mathrm{~g} \mathrm{l}^{-1}$ ) gave low activities 
which increased rapidly as the assay $\mathrm{pH}$ was increased above $5 \cdot 0$, to reach a maximum of 340 units at $\mathrm{pH} 8.0$. This is only about $25 \%$ of the value obtained in carbon-limitation and again ultrasonication of the cells did not increase the activity. Phosphate-limitation was not used in any other experiments.

The growth $\mathrm{pH}$ also affected the phosphatase activity. For cells grown at $\mathrm{pH} 6 \cdot 0,7 \cdot 0$ and $8 \cdot 0$ the phosphatase specific activities (assayed at $\mathrm{pH} 7 \cdot 0$ ) were $1170 \pm 63,1473 \pm 34$ and $589 \pm 14$ (mean \pm SEM; six determinations using cells from two chemostats) units respectively; i.e. growth at $\mathrm{pH} 7.0$ significantly elevated the activity $(P=0.95)$ over that obtained at the other two $\mathrm{pH}$ values while growth at $\mathrm{pH} 8.0$ reduced it markedly. Similar results were obtained with each type of cell assayed at $\mathrm{pH} 6.0$ and 8.0 , and as with previous experiments the protein content per $\mathrm{mg}$ dry weight was invariant.

\section{Effect of phosphatase inhibitors}

Adding inorganic phosphate to the assay mixture, which commonly causes competitive inhibition of alkaline phosphatases but not acid phosphatases (Fernley, 1971; Bolton \& Dean, 1972; Kawabe et al., 1981) had a negligible effect on the phosphatase activity of carbon-limited organisms: more than $95 \%$ of the initial activity was retained in the presence of $0.5-10.5 \mathrm{~mm}$ $\mathrm{HPO}_{4}^{2-}$ irrespective of the assay $\mathrm{pH}$ (16 determinations, cells from two chemostats).

EDTA is also a potent inhibitor of alkaline phosphatases with, in typical mammalian systems, a $50 \%$ loss in activity at only $0.6 \mathrm{~mm}$ concentration (Van Belle, 1972). However, the phosphatase activity of the Citrobacter sp. at $\mathrm{pH} 5 \cdot 0, \mathrm{pH} 7.0$ and $\mathrm{pH} 8.5$ was unaffected by EDTA $(0 \cdot 15-3.10$ $\mathrm{mM}$ ), in accordance with the finding that exogenous $\mathrm{Mg}^{2+}$ is not required for activity (see above).

Other organic compounds also diagnostically inhibit alkaline phosphatases (Butterworth, 1983). These include theophylline (Fawaz \& Tejirian, 1972), imidazole (Brunel \& Cathala, 1972) and L-phenylalanine (Ghosh \& Fishman, 1966; Byers et al., 1972), the latter exerting its activity in Escherichia coli by preventing active dimer formation (Neuman \& Lustig, 1980). The phosphatase activity of the Citrobacter $\mathrm{sp}$. was insensitive to phenylalanine $(0 \cdot 3-6 \cdot 0 \mathrm{~mm})$ at all $\mathrm{pH}$ values. Imidazole (Fig. $1 a$ ) and theophylline (Fig. $1 b$ ) had little effect at $\mathrm{pH} 7$ at the concentrations tested and gave only slight inhibition at $\mathrm{pH} 8.5$, while, surprisingly, a concentration-dependent stimulation of activity (small in the case of imidazole) was observed at pH 5 .

These results argue against the participation of an alkaline phosphatase in the enzyme activity observed at $\mathrm{pH} 8.5$ in carbon-limited cells. The broad $\mathrm{pH}$ optimum $(\mathrm{pH} 5.0-8.5)$, which contrasts with the much sharper peaks in activity observed at acid $\mathrm{pH}$ values only with the acid phosphatases of Klebsiella aerogenes (K. pneumoniae) (Pickett et al., 1976) and of Bacillus subtilis 'subsp. niger' and a Pseudomonas sp. (Pickett \& Dean, 1977), together with the very different pH-activity profile reported above for phosphate-limited organisms (in which alkaline phosphatase synthesis would be derepressed) compared to carbon-limited organisms, supports the conclusion that an atypical acid-type phosphatase operates at all $\mathrm{pH}$ values. The action of fluoride provided further evidence.

Inhibition by fluoride is a common property of bacterial acid phosphatases, and the Citrobacter enzyme was inhibited by this anion (Fig. $1 a$ ). At pH 5.0 about $90 \%$ of the initial activity was lost at a concentration of only $2.5 \mathrm{~mm}-\mathrm{F}^{-}$, higher concentrations having no further effect (Fig. 1 $a$ ), findings similar to those of Torriani (1960) and Bolton \& Dean (1972) with $E$. coli and $K$.aerogenes ( $K$. pneumoniae) respectively. The degree of inhibition decreased at $\mathrm{pH} 7 \cdot 0$ and $\mathrm{pH} 8.5$ (Fig. $1 a$ ). In contrast, formaldehyde was most inhibitory at $\mathrm{pH} 7.0$ although marked inhibition was also apparent at $\mathrm{pH} 5.0$ and $\mathrm{pH} 8.5$ (Fig. $1 \mathrm{~b}$ ). This behaviour contrasts sharply with that of the acid phosphatases of $K$. aerogenes (K. pneumoniae) (Bolton \& Dean, 1972) and of B. subtilis'subsp. niger' and a Pseudomonas sp. (Pickett \& Dean, 1977), which were unaffected by formaldehyde (130 mM), further illustrating the atypical nature of the Citrobacter enzyme.

\section{Effect of heavy metals on phosphatase activity}

Metals are required at very low levels as enzyme activators or as components of metalloenzymes (Lazdunski et al., 1969; Linden et al., 1977), but they are inhibitory at high concentrations (Vallee \& Ulmer, 1972). 

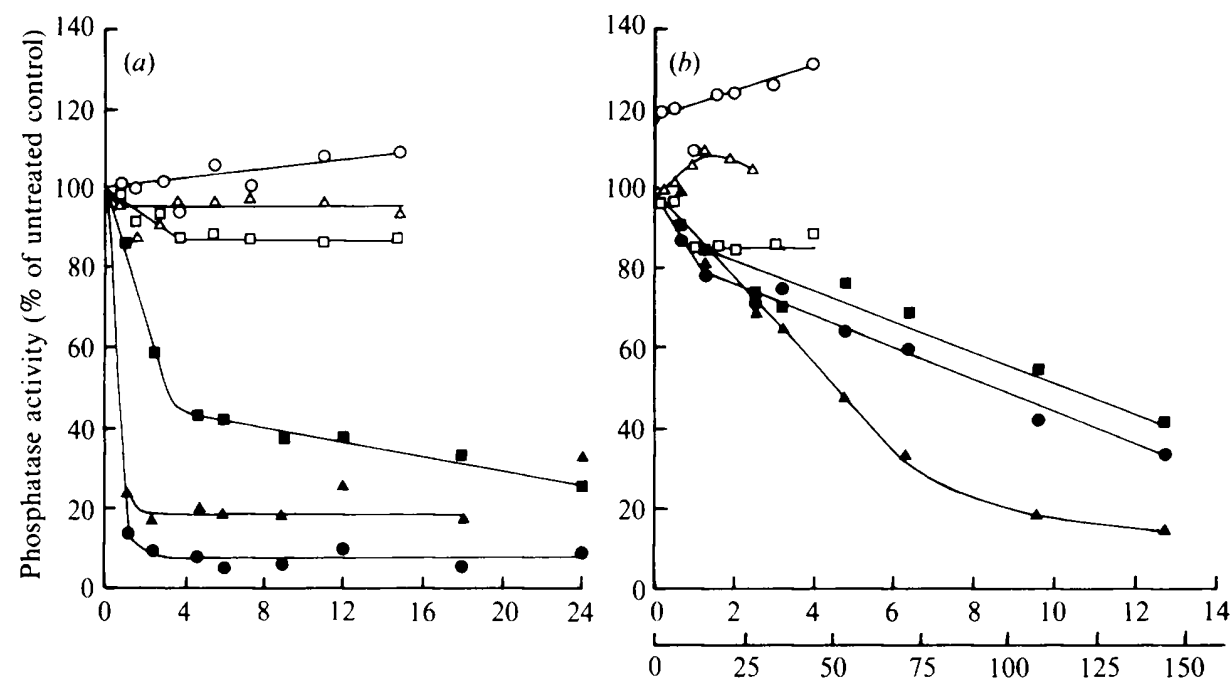

Concentration ( $\mathrm{mm})$

Fig. 1. Effect of phosphatase inhibitors on the phosphatase activity of Citrobacter sp. The cells were grown at $D=0.5 \mu_{\max }$ and pre-exposed to the inhibitors for $1.5 \mathrm{~h}$ prior to assay for phosphatase activity. (a) Effect of fluoride (filled symbols) and imidazole (open symbols). (b) Effect of formaldehyde (filled symbols, lower scale) and theophylline (open symbols, upper scale)., 0, MES buffer (pH 5.0); $\Delta, \Delta$ MOPS buffer ( $\mathrm{pH} 7 \cdot 0): \square, \square$. Tricine buffer ( $\mathrm{pH} \mathrm{8.5).} \mathrm{Results} \mathrm{are} \mathrm{mean} \mathrm{values} \mathrm{from} \mathrm{two} \mathrm{chemostats} \mathrm{and}$ the control $(100 \%)$ value was 1349 units.

The sensitivity of the phosphatase of the Citrobacter sp. to heavy metals was investigated

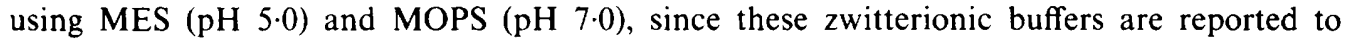
complex heavy metals minimally (Good et al., 1966), in contrast to acetate (see Nriagu, 1981) and Tris (Brignac \& Mo, 1975). However, at pH 8.5 in non-complexing conditions, metal hydroxides would precipitate freely. A compromise was employed by using Tricine buffer which, although complexing with metals, especially copper, does so to a much smaller extent than Tris (Good et al., 1966; Brignac \& Mo, 1975).

At pH 5.0 and 8.5 cobalt and nickel had little effect on phosphatase activity, values within $\pm 8 \%$ of the control (metal-unsupplemented) level being obtained at eight metal concentrations in the range $0 \cdot 18-17 \cdot 0 \mathrm{mM}$ (cells from two chemostats). Both metals were slightly more inhibitory at $\mathrm{pH} 7.0$ but the effect was again concentration-independent. Expressed as a percentage of the control activity (1349 units) the values obtained at $\mathrm{pH} 7.0$ were $87.56 \% \pm 2.38$ and $82.31 \% \pm$ 1.89 (means \pm SEM; 16 determinations) for cobalt and nickel respectively. At $\mathrm{pH} 8.5$ the copperTricine coordination complex which formed similarly caused only about $7 \%$ inhibition, independently of the copper concentration (Fig. $2 a$ ) up to $16 \mathrm{~mm}$, the highest concentration tested. At pH 5.0 marked inhibition occurred (Fig. $2 a$ ), activity being reduced to about $30 \%$ at $0.8 \mathrm{~mm}$-copper and to only $3 \%$ at concentrations above $10 \mathrm{~mm}$. Copper was not very soluble in MOPS at $\mathrm{pH} 7$ but nevertheless, even at the highest concentration possible $(0.28 \mathrm{~mm})$, activities of only $11 \%$ and $9 \%$ of the control values were obtained in two independent experiments.

Zinc is a potent non-competitive inhibitor of mammalian phosphatases (Linden et al., 1977). However, the Citrobacter phosphatase was immune to zinc toxicity at $\mathrm{pH} 8.5$, while at $\mathrm{pH} 5$ about $15 \%$ of the activity was lost, the effects at both $\mathrm{pH}$ values being largely independent of the zinc concentration (Fig. $2 a$ ). In contrast, greater inhibition occurred at pH 7.0 (Fig. 2a), where only $62 \%$ of the control activity remained at $0.8 \mathrm{~mm}$-zinc; activity decreased linearly with $\log _{10}$ (zinc concentration), to $6.5 \%$ of the control value at $3.8 \mathrm{~mm}$-zinc.

As postulated earlier (see Introduction) the phosphatase was very resistant to cadmium. Very similar results were obtained at all three $\mathrm{pH}$ values up to about $10 \mathrm{~mm}$-cadmium, where the residual activity was $80 \%$ of the metal-free control (Fig. $2 b$ ). At higher cadmium concentrations activity declined linearly with $\log _{10}$ (cadmium concentration). The effect of cadmium at 


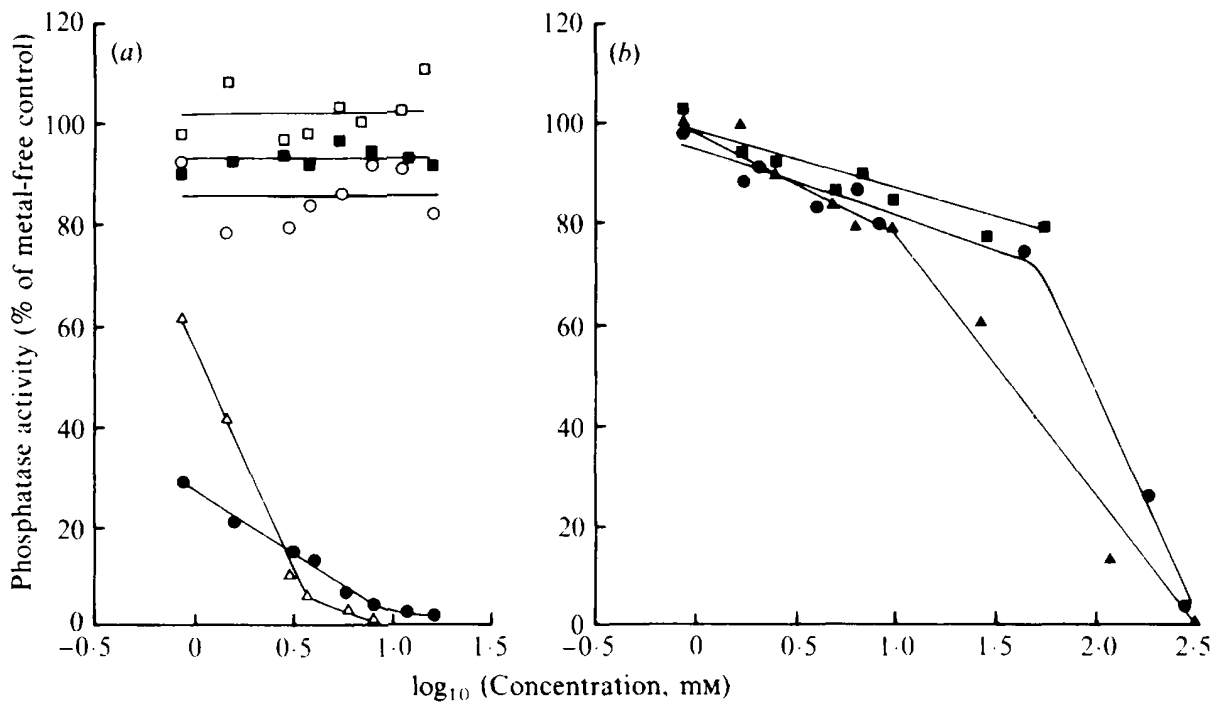

Fig. 2. Effect of heavy metals on the phosphatase activity of Citrobacter sp. Conditions were as in Fig. 1. (a) Effect of copper (filled symbols) and zinc (open symbols): (b) effect of cadmium. 0,0 , MES

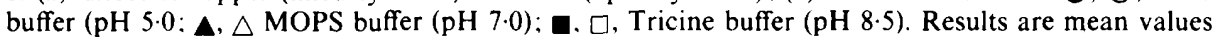
from two chemostats.

concentrations higher than $56 \mathrm{~mm}$ could not be tested at $\mathrm{pH} 8.5$ due to its low solubility at alkaline $\mathrm{pH}$, but up to this concentration the results obtained at $\mathrm{pH} 5$ and 8.5 were very similar (Fig. $2 b$ ). The limited of tolerance of the enzyme at acid $\mathrm{pH}$ corresponded to a cadmium concentration of $50 \mathrm{~mm}$; above this concentration the activity fell linearly with $\log _{10}$ (cadmium concentration). However, it was only reduced to $50 \%$ of its initial level by $94.4 \mathrm{~mm}$-cadmium (i.e. $\left.10.6 \mathrm{~g} \mathrm{l}^{-1}\right)$, while to reduce it to a negligible level required the presence of $290 \mathrm{~mm}$-cadmium in the assay mixture (Fig. $2 b$ ). As might be expected for metals within the same group, the pattern of resistance to cadmium and zinc was similar (although the overall resistance to cadmium was greater): compare Figs $2(a)$ and $2(b)$.

The possibility that the high concentrations of cadmium employed (up to $290 \mathrm{~mm}$ ) had an osmotic effect on the cells was discounted by the incorporation of an ionically equivalent amount of $\mathrm{Na}_{2} \mathrm{SO}_{4}$ into the assay buffers (cadmium-free). Under these conditions the phosphatase activity was unaffected and the inhibition reported above was concluded to be metal-mediated.

\section{REFERENCES}

AHLERS, J. (1974). Kinetics of alkaline phosphatase from pig kidney. Mechanism of activation by magnesium ions. Biochemical Journal 141, 257-263.

Aickin, R. M., Dean, A. C. R., Cheetham, A. K. \& SKaRnulis, A. J. (1979). Electron microscope studies on the uptake of lead by a Citrobacter sp. Microbios Letters 9.7. 15

Bolton, P. G. \& Dean, A. C. R. (1972). Phosphatase synthesis in Klebsiella (Aerobacter) aerogenes growing in continuous culture. Biochemical Journal 127. $87-96$

Brignac, P. J. \& Mo, C. (1975). Formation constants and metal-to-ligand ratios for tris(hydroxymethyl)aminomethane-metal complexes. Analytical Chemistr. 47, 1465-1466.

BRunel, C. \& Cathala, G. (1972). Imidazole, an inhibitor of L-phenylalanine-insensitive alkaline phosphatase of tissues other than intestine and placenta. Biochimica et biophysica acta 268. 415-421.
Butterworth, P. J. (1983). Alkaline phosphatase. Biochemistry of mammalian alkaline phosphatase. Cell Biochemistry and Function 1, 66-70.

Byers, D. A. Fernley, H. N. \& Walker, P. G. (1972). Studies on alkaline phosphatase: inhibition of human placental phosphoryl phosphatase by Lphenylalanine. European Journal of Biochemistry 29. $197-204$.

Fawaz, E. N. \& Tejirian, A. (1972). Inhibition of alkaline phosphatase by theophylline in vitro. HoppeSeyler's Zeitschrift für physiologische Chemie 353, $1779-1783$

FERNLEY, H. N. (1971). Mammalian alkaline phosphatases. In The Enzymes vol. 4, pp. 417-447. Edited by P. D. Boyer. New York: Academic Press.

Ghosh. N. K. \& Fishman, W. H. (1966). On the mechanism of inhibition of intestinal alkaline phosphatase by L-phenylalanine. I. Kinetic studies. Journal of Biological Chemistry 241, 2516-2522. 
Good, N. E., Winget, G, D., Winter, W., ConNOLLY, T. N.. IZAWA, S. \& Singh, R. M. M. (1966). Hydrogen ion buffers for biological research. Biochemistry 5, 467477

Hausamen, T. U.. Helger, R., Ric, W. \& Gross. W. (1967). Optimal conditions for the determination of serum alkaline phosphatase by a new kinetic method. Clinica chimica acta 15, 241-245.

Kawabe, H.. Sugiura, Y. \& Tanaka, H. (1981). ${ }^{3}$ P

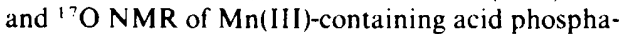
tase. Biochemical and Biophysical Research Communications 103, 327-331.

Lazdunski, C., Petitclerc, C. \& Lazdunski, M (1969). Structure function relationships for some metalloalkaline phosphatases of Escherichia coli. European Journal of Biochemistry 8, 510-517.

Linden, C., Chappelet-ToRdo, D. \& Lazdunski, M. (1977). Milk alkaline phosphatase. Stimulation by $\mathrm{Mg}^{2+}$ and the properties of the $\mathrm{Mg}^{2+}$ site. Biochimica et biophysica acta 483, 100-106.

Macaskie, L. E. \& Dean, A. C. R. (1982). Cadmium accumulation by micro-organisms. Environmental Technology Letters 3, 49-56.

Macaskie, L. E. \& Dean, A. C. R. (1984a). Cadmium accumulation by a Citrobacter sp. Journal of General Microbiology 130, 53-62.

MaCaskie, L. E. \& Dean, A. C. R. (1984b). Cadmium accumulation by immobilized cells of a Citrobacter sp. Encironmental Technologi Letters 5, 177- 186.

Macaskie, L. E. \& Dean, A. C. R. (1984c). Heavy metal accumulation by immobilized cells of a Citrohacter sp. Biotechnology Letters 6, 71-76.

MaCaskie, L. E. \& DeAN, A. C. R. (1985a). Uranium accumulation by immobilized cells of a Citrobacter sp. Biotechnology' Letters 7, 457-462.

Macaskie. L. E. \& Dean, A. C. R. (1985b). Strontium accumulation by immobilized cells of a Citrobacter sp. Biotechnology Letters 7, 627630.

MACASKIE, L. E. \& Dean, A. C. R. (1987). Use of immobilized biofilm of Citrobacter sp. for the removal of uranium and lead from aqueous flows Enzyme and Microbial Technology 9, 2-4

Macaskie, L. E., Wates, J. M. \& Dean, A. C. R (1987a). Cadmium accumulation by a Citrobacter sp. immobilized on gel and solid supports: applicability to the treatment of liquid wastes containing heavy metal cations. Biolechnology and Bioengineering (in the Press)

Macaskie, L. E., Dean, A. C. R., Cheetham. A. K., Jakeman, R. J. B. \& SKarnulis, A. J. $(1987 h)$.
Cadium accumulation by a Citrobacter sp.: the chemical nature of the accumulated metal precipitate on the bacterial cells. Journal of General Microbiology 133, 539-544.

MCCOMB, R. B. \& Bowers, G. N., JR (1972). Study of optimum buffer concentrations for measuring alkaline phosphatase activity in human serum. Clinical Chemistry 18, 97-104

Michel, L. J., Macaskie, L. E. \& Dean, A. C. R. (1986). Cadmium accumulation by immobilized cells of a Citrobacter sp. using various phosphate donors. Biotechnology and Bioengineering 28, 1358-1365.

Mossner, E., Boll, M. \& Pfleiderer, G. (1980). Purification of human and bovine alkaline phosphatase by affinity chromatography. Hoppe-Seyler's Zeitschrift für physiologische Chemie 361, 543-549.

NELMAN, H. \& LuSTIG, A. (1980). The activation of alkaline phosphatase by effector molecules. European Journal of Biochemistry 109, 475-480.

NRIAGU, J. O. (1981). Production, uses and properties of cadmium. In Cadmium in the Environment, Part I, Ecological Cycling, p. 43. Edited by J. O. Nriagu. New York: Wiley.

Pickett, A. W. \& Dean, A. C. R. (1977). Phosphatase activities of cadmium- and zinc-resistant strains of Bacillus subtilis subsp. niger and of a Pseudomonas sp. Microbios Letters 6, 103-109.

Pickett, A. W., Carter, I. S. \& Dean, A. C. R. (1976). Enzymic activities of cadmium- and zinc-tolerant strains of Klebsiella (Aerobacter) aerogenes growing in glucose-limited chemostats. Microbios 15, 105111.

Sugilra, Y., Kawabe, H., Tanaka, H., Fujimoto, S. \& OHara, A. (1981). Purification, enzymatic properties and active site environment of a novel manganese(III)-containing acid phosphatase. Journal of Biological Chemistry. 256, 10664-10670.

Tempest, D. W. (1984). In Continuous Culture 8: Biotechnology: Medicine and the Entironment, p. 318. Edited by A. C. R. Dean, D. C. Ellwood \& C. G. T. Evans. Chichester: Ellis Horwood.

TORRIANI, A. (1960). Influence of inorganic phosphate in the formation of phosphatases by Escherichia coli. Biochimica et biophysica acta 38, 460-479.

VALLEE, B. L. \& Ulmer, D. D. (1972). Biochemical effects of mercury, cadmium and lead. Annual Review of Biochemistry 41, 91-128.

VAN Belle, H. (1972). Kinetics and inhibition of alkaline phosphatases from canine tissues. Biochimica et biophysica acta 289, 158168. 